\title{
The Neoliberal Underpinnings of the Bioeconomy: the Ideological Discourses and Practices of Economic Competitiveness
}

\section{KEAN BIRCH}

\begin{abstract}
When we talk about ideology and new genetics we tend to think of concepts like geneticisation and genetic essentialism, which present genetics and biology in deterministic terms. However, the aim of this article is to consider how a particular economic ideology - neoliberalism - has affected the bioeconomy rather than assuming that it is the inherent qualities of biotechnology that determine market value. In order to do this, the paper focuses on the discourses and practices of economic competitiveness that pervade biotechnology policy-making in the UK, Europe and the USA. Finally it will consider how the manufacture of scarcity - in order to produce the bioeconomy - has led to a problematic focus on a specific innovation paradigm that may prove detrimental to the development and distribution of new biotechnologies.
\end{abstract}

\section{Introduction}

When we talk about ideology in reference to genetics, we tend to think of concepts such as Lippman's geneticisation ${ }^{1}$ and Nelkin and Lindee's genetic essentialism ${ }^{2}$ that emerged during the 1990s. More explicitly, Katz Rothman has stated that "Genetics isn't just a science. It's becoming more than that. It's a way of thinking, an ideology", 3 and Richard Lewontin has argued that biological determinism is an ideology. ${ }^{4}$ Several other academics have made similar claims, ${ }^{5}$ whilst this conceptual focus on the impact of new genetics technologies on our societies, social relations and personal lives has been addressed in numerous studies. ${ }^{6}$ However, there has been a growing number of questioning voices, which both criticise concepts like geneticisation and genetic essentialism on the one hand and provide a more 'positive' analysis of the influence of new genetics on the other. In particular Hedgecoe has argued that the concept of geneticisation implicitly identifies genetic technologies in a wholly negative light and is therefore in some ways a compromised perspective. ${ }^{7}$ Thus whilst geneticisation may provide insight at broad social level it does not address the more immediate and personal impacts of the new technologies. ${ }^{8}$ Furthermore, other scholars have questioned the empirical basis of geneticisation itself, arguing that the evidence for claims that genetics has colonised social life are not substantiated by the evidence, ${ }^{9}$ although research also questions this view as well. ${ }^{10}$

Instead of focusing on the ideological discourses around the biological and genetic basis of the bioeconomy, this article argues that economic ideologies have played a more significant role in producing the current biotech industry and its market. In particular, the ideological discourse of neoliberalism provides a particularly pertinent perspective to illustrate how the bioeconomy results from a specific set of economic representations and practices. ${ }^{11}$ This provides a theoretical approach that does not 
exclude social and political concerns, ${ }^{12}$ in contrast to genetic ideology arguments which Kerr has argued are problematic because:

'Foregrounding the transformative effects of technologies takes attention away from the social circumstances in which they are developed, and the extent to which they reinforce old cultural values and social arrangements, rather than introduce new ones. ${ }^{13}$

There is a very real sense in which the individualisation of new genetics enables 'hype' and promises of future health to promote new technologies and constitute specific economic spaces ${ }^{14}$ which has important political economic implications for the bioeconomy. Thus Fleising and Caulfield (and others) argue that 'genohype' has an important promotional role in the production of certain visions around these new technologies that drives the commercialisation of technoscience. ${ }^{15}$

In order to produce this analysis it is first necessary to clarify what I describe as economic representations and economic practices. The former can be seen as the ways we map and pattern a specific set of values onto the description of a particular thing. Such representational discourses entail a series of assumptions and expectations about the values of actors, groups and even societies. For example, Mitchell argues that certain neo-institutional and neoliberal discourses represent a world without 'property rights' as inherently chaotic. ${ }^{16}$ Consequently such representations consist of an expectation about the world (ie, it describes how the world works) that enables action to be undertaken (ie, people know what will happen when they act in the world). Furthermore, in their work on the sociology of technological expectations Brown and Michael claim that this tendency to fetishise the "soon to be" naturalises current actions by making them appear as the obvious and therefore inevitable solution to a particular problem. ${ }^{17}$ However, the diversity and variety of representational discourses means that the world they describe leads by necessity to certain practices that they also prescribe.

Whether the discourse describes a 'concrete' world is irrelevant in the justification for these practices because there is no need for a link to be made between the description and prescription because the latter is always one-step removed. Our experience of our practices occurs after our experience of its representation because we have acted upon an expectation about the world. When there is a fracture between the two, this can be easily re-represented in new terms that re-naturalise and re-justify any dissonance between such representations and practices. What is notable, however, is that this process can produce self-fulfilling prophecies in which social actors acting upon the representation of the world reinforce their expectations through their performance. ${ }^{18}$ This performance makes such actors appear predictable and therefore trustworthy, although only because they reinforce a particular description. ${ }^{19}$

In order to explore these issues, this article builds on this outline of how representations and practices operate together to produce legitimating mechanisms for particular policies that then produce a self-fulfilling prophecy as practices are naturalised and normalised. The example used to illustrate this argument is the policy discourse around the importance of competitiveness in the bioeconomy and how this has naturalised and justified policy changes to institutions directly impacting the biotech innovation system. I argue that the concept of neoliberalism helps to explain 
how we might understand the discourses and practices underpinning bioeconomy as part of a particular economic ideology. Finally I will consider how this ideology has impacted the bioeconomy.

\section{Neoliberal underpinnings of the bioeconomy}

The work of Karl Polanyi on the embeddedness of markets and economic activity in social relations provides a useful approach to adopt when considering the bioeconomy. ${ }^{20}$ Rather than rejecting the insights of economic sociology and economic anthropology, it is worth taking into account the important place that 'choice' plays in market economies and how choice is manufactured through the production of scarcity. According to Polanyi the 'formal' side of economics relating to means-end relationships is tied to such choice. This is achieved through the withholding of resources via either "Nature or Law" leading to the "introduction of purchasing power as a means of acquisition" which then "converts the process of meeting requirements into an allocation of insufficient means with alternative uses, namely, money". ${ }^{21}$ Central to this process is the control of access to production inputs (eg, labour) and distributional outputs (eg, markets) through mechanisms such as intellectual property. It is especially crucial to note that markets are based on the relationship between people rather than people and resources, which means that scarcity and therefore market value is manufactured through the acquisition of a resource by a person(s) and the exclusion from the same resource for other people. Thus market value is not based on any intrinsic quality of the resource itself nor, therefore, on any ability to calculate its market value except as the result of induced scarcity.

What this means for the bioeconomy is that the political economy of biotechnology ie, how it is organised as a market - can be seen as the consequence of the expansion of specific economic discourses and practices. In particular, the bioeconomy is tied to the rise of neoliberalism as the dominant mode of governance. Neoliberalism itself developed as an economic ideology for two major reasons. First, it was a response to the totalitarian regimes of Nazi Germany and Soviet Russia. Second, it resulted from a concern with the 'problem of knowledge' in economic calculation, which meant that a centrally-planned market was not seen as plausible. ${ }^{22}$ The term itself was coined in 1938 at a meeting in Paris of liberal intellectuals - including the likes of von Mises and Hayek - who focused on "the redefinition of the functions of the state" to ensure the development of freedom and property rights (ie, market ethics) and contrasted with the nineteenth century laissez faire liberal tradition based on removing state intervention altogether. ${ }^{23}$ It also had a strong international dimension in seeking to promote peace and freedom through international economic exchange. This early movement was cemented after World War II with the establishment of the Mont Pelerin Society in 1947, although neoliberalism itself failed to dominate economic discourse during the post-war period, which was instead characterised by a form of Keynesian 'embedded liberalism'. ${ }^{24}$

It was not until the 'fiscal crises' of the early 1970s and especially the erosion and subsequent collapse of the Bretton Woods system that neoliberalism became the dominant political economic perspective. ${ }^{25}$ The growing influence of neoliberalism can be seen as the consequence of the amalgamation of a number of strands of 
political economic thought such as monetarism, rational expectations, supply-side economics and public choice. ${ }^{26}$ Allied to this array of theories, and crucial to the expansion of neoliberalism, were a range of new and established organisations, foundations and associations, including the Institute of Economic Affairs (est.1955) in the UK and the World Economic Forum (est.1971), that helped to expound neoliberal perspectives. ${ }^{27}$ Furthermore, the problematisation of knowledge also proved crucial because it laid the foundations for the ascendancy of the "logics of competitiveness", ${ }^{28}$ which is evident in the economic and policy debates around innovation and technological change central to the analysis of the bioeconomy.

There is a dual process at work here underpinning much of the competitiveness discourse around the bioeconomy and its simultaneous practice. On the one hand practices (eg, patenting) must encourage and promote innovation and the capacity of commercial actors to enter (ie, make) new markets so that the market can spread into new areas of life. On the other hand innovation has to be represented as a natural process in which 'fitness' (ie, success) is (re)presented as a consequence of inherent and endogenous competitiveness thereby justifying and naturalising a specific set of practices. ${ }^{29}$ Thus innovation has to be presented as the consequence of innate and internal characteristics because competitiveness would otherwise merely represent the application of power - eg, the ability to spend more on innovation, the ability to bully other countries during trade negotiations, etc. ${ }^{30}$ If we take the latter point seriously we have to consider how this has been instigated and pursued through specific policy processes and what implications this has for the bioeconomy.

These processes can be seen as part of a shift identified by Jessop and others from a Keynesian welfare national state to a Schumpeterian workfare post-national regime. ${ }^{31}$ More simply this can be classified as the rise of a neoliberal regime in which market values are installed as the over-riding ethic in society. ${ }^{32}$ There is a growing body of work in economic geography, in particular, along with other disciplines exploring these processes. With neoliberalism defined as the "mobilization of state power in the contradictory extension and reproduction of market(-like) rule", ${ }^{33}$ these scholars have mapped out a number of distinct phases. Peck and Tickell, for example, have described three stages starting with 'proto-neoliberalism' in the 1970s, which sought to establish the philosophical basis for free markets and thereby influence economic thinking in academic and policy debates. The subsequent mobilisation of state power initiated the 'roll-back neoliberalism' of the 1980s, which focused on deregulation and privatisation across institutions previously tied to Keynesian principles. Finally, the economic contradictions inherent in the neoliberal project led to the 'roll-out neoliberalism' of the 1990s in which government intervention and institution building is directly tied into new forms of governance. ${ }^{34}$ Thus the state's current role is characterised as a facilitator of market forces, which contrasts with the claims that the state is 'withering away' or 'hollowing out', 35 and consequently neoliberalism has led to new disciplinary and coercive modes of governance "in order to impose market rule upon all aspects of social life". ${ }^{36}$

As mentioned above, neoliberalism arose from an array of theories and concepts that have enormous influence in both competitiveness discourse and practice. In an especially interesting analysis of this second 'great transformation,' Blyth details the multiple strands of thought that helped to produce neoliberal ideology. ${ }^{37}$ Of particular 
interest are the links between economists like Hayek and von Mises and early proponents of the 'knowledge economy' thesis, such as Fritz Machlup, Daniel Bell and Michael Polanyi. ${ }^{38}$ The 1990 s revival of such concepts as the knowledge economy with their implicit links between innovation and competitiveness are worth considering in light of these earlier neoliberal assumptions and arguments around the role of knowledge. ${ }^{39}$ Thus playing out across these arguments is the legitimating discourse of economic development that permeates the bioeconomy as the Triple Helix model of Etzkowitz and Leydesdorff illustrates. ${ }^{40}$ Neoliberal concepts and theories therefore serve to show how institutional features of markets have a crucial impact on innovation and can be sites of policy action and change at the same time that action in other areas is denigrated.

In this sense we can see that the biotech market has not developed in response to the intrinsic qualities of new genetics; nor have the new genetic technologies developed in response to their own intrinsic qualities. Instead biotechnology fits squarely within the broader move from Keynesian economics to neoliberalism. Such a move is not automatic and has been described by Harvey as a "utopian project...[and] a political project to re-establish the conditions for capital accumulation and to restore the power of economic elites". ${ }^{41}$ There are a number of institutional discourses and practices that legitimate and enact this neoliberal project, ${ }^{42}$ producing the scarcity needed to ensure the manufacture of a market for new genetic technologies. According to both $\mathrm{Bud}^{43}$ and Loeppky ${ }^{44}$ biotechnology promised potentially huge returns for investors, a promise that was then embedded in specific institutional forms like the 'dedicated biotech firm' (DBF). This is because such small and 'innovative' firms (ie, those benefiting from public investment in science and policy changes) produce higher returns because any technological 'breakthrough' or promise has a greater proportional impact on their market value than for any large firm. ${ }^{45}$ Furthermore, the political economy of biotechnology is built on the back of monopoly profits in markets established by policies designed to stimulate innovation (eg, the US Orphan Drugs Act in 1983) through the production of scarcity in a market characterised by increasing returns to scale. ${ }^{46}$ Thus the scientific infrastructure provided by massive historical and contemporary public spending on biomedicine means that the high, fixed costs of biomedical research precludes the pursuit of such endeavours by any single firm, no matter how large, but also ensures that the marginal returns from private investment produce monopoly profits. ${ }^{47}$

\section{Competitiveness in discourse and practice}

\section{Representations of the bioeconomy: policy discourse on competitiveness}

The central aim here is to outline the emphasis in policy discourse on the revolutionary impact that genetics, genomics and other 'modern' biotechnologies have had and will have on our society, polity and, increasingly, our economy. In particular I want to illustrate the ongoing concern with competitiveness before showing how this has been constituted through deliberate policy action. Recent examples of this discourse include the debates in the European Commission and the Organisation for Economic Co-operation and Development on the 'bioeconomy' ${ }^{48}$ In one instance, the EU Science and Research Commissioner claims that the 'knowledge-based bio-economy' is worth in the region of $€ 1.5$ trillion annually and 
that consequently it is an important "driver of growth and competitiveness". 49 In turn the OECD aims to examine the "policies needed to promote and exploit this new wave of innovations to promote high-level social and economic goals" ${ }^{50}$ However, such discourse also emphasises a strong link between the economic success of biotechnology and the improvement of national healthcare, primarily, alongside other issues. $^{51}$

Such concerns with innovation, growth and competitiveness are reiterated in the policy discourse of the UK national and devolved governments. The former is particularly evident in the terms of reference of the Bioscience Innovation and Growth Team (BIGT) to "identify and clarify the issues that are critical to the future competitiveness of the UK biosciences sector", especially in relation to healthcare. ${ }^{52}$ There is again a clear association between national competitiveness and national healthcare in the policy discourse throughout the BIGT report. ${ }^{53}$ A key element in this discourse is the identification of successful innovation and particularly the fruits of healthcare R\&D like biopharmaceuticals. Consequently a number of mapping exercises have been pursued by the DTI and other organisations such as EuropaBio, the European trade organisation. ${ }^{54}$ These build upon earlier policy reports such as the Biotech Clusters and Genome Valley produced by the DTI at the end of the 1990s. ${ }^{55}$ However, what sets the later analyses apart is the clearer identification of the biosciences - in itself a broader term - with economic competitiveness and from this national well-being. ${ }^{56}$

At both the devolved and regional level there is also a strong emphasis on the importance of the biosciences in policy discourse, in part inspired by the continuing 'knowledge economy' claims that permeate much of this debate. Almost all the Regional Development Agencies (RDAs), for example, have some policy drive to promote the biosciences, biotechnology, life sciences etc. In particular Scotland has developed a Scottish Life Sciences Strategy with the explicit aim to construct a "globally focused, sustainable life sciences sector" that is less concerned with national healthcare per se and instead concentrates on competitiveness. ${ }^{57}$ Such activities build upon earlier activities that Scottish policy-makers (eg, Scottish Enterprise) had developed such as the 1999 'cluster' strategy; this covered not only biotechnology but other 'knowledge' sectors as well. ${ }^{58}$ A number of initiatives were undertaken as a consequence of such policy discourse, not all of which were necessarily successful in promoting innovation or competitiveness. ${ }^{59}$ The cluster-promoting strategy is reproduced in regional policy discourse in England as well with a number of regional organisations and bodies presenting the biotech cluster as a self-evident fact rather than questionable policy strategy. ${ }^{60}$ Others have been more cautious though. ${ }^{61}$

It is important to note that this policy discourse is neither new nor unique to the UK, or to Europe and the USA. We can find examples of much earlier policy debates in the UK, and there are numerous instances of such concerns in European and American policy circles. In fact there appears to be an ongoing concern with the performance of the US that permeates European policy discourse to the extent that the US biotechnology industry has achieved an almost 'mythic' status. ${ }^{62}$ Early instances of this fear of lost competitiveness can be found in the UK with the 1980 Spinks Report explicitly identifying a number of national competitors like the US, West Germany, France and Japan. Again the report characterises biotechnology (and not 
the biosciences or life sciences) as an "area of high technology with large potential growth offering opportunities" that necessitates swift action to "both remove these [constraints] and to promote biotechnology". ${ }^{63}$ A later House of Lords report, from the early 1990s, claims that the UK biotech industry has a "competitive disadvantage" over the US and Japan in particular and again emphasises the "enormous future benefits to mankind". ${ }^{64}$ There is little difference in early US policy discourse, ${ }^{65}$ which, once it had moved beyond concerns with safety, concentrated on the commercialisation of biotechnology and the competitive position of the US in comparison to other countries. ${ }^{66}$ Even as early as 1977 the US Senate was highlighting the main risk in the biotechnology industry as the possibility of "losing out on a novel field with immense commercial impact". ${ }^{67}$

Both policy and academic debates define the concept of competitiveness as 'success' in international markets. ${ }^{68}$ Consequently competitiveness itself represents a discourse that justifies and naturalises the pursuit of specific policies that ensure success in these markets through the (re)constitution of national institutional frameworks. The representation of the biosciences as a driver of competitiveness throughout the regional, national and supranational policy discourses can be seen as a process in which biotechnology has been presented as an obvious and perhaps even inevitable solution to such policy concerns. The more recent link between competitiveness and national well-being or healthcare embeds this competitiveness concern in the intrinsic attributes of biotechnology itself so that the previous emphasis on the bioeconomy appears rational and obvious; ${ }^{69}$ who does not want better drugs or less pollution after all? Competitiveness can therefore be presented as technologically determined and dependent upon innovation, which leads to a self-fulfilling prophecy as changes made to institutional structures to encourage bioscience innovation benefit all firms and not just national ones. In this way the external threat presented in the competitiveness discourse becomes concrete as external firms can enter newly (institutionally) deregulated markets more easily than firms based in those markets because the latter have to adapt to new institutions whilst the former do not because they have not been embedded in the previous institutional environment. Furthermore the emphasis on the need to continually upgrade technology through innovation in order to compete leads to the gradual expansion and privatisation of global capital as country after country deregulates in order to avoid any form of competitive disadvantage. ${ }^{70}$

\section{Practices of the bioeconomy: manufacturing scarcity}

The policy discourse around innovation and competitiveness has led to the embedding of a number of specific institutional changes in the US bioeconomy that have had enormous influence on other countries. At least three such components to the competitiveness regime have been naturalised as necessary policy changes intended to ensure success in the bioeconomy. First and foremost was the ability to capture returns on the new biotechnologies arising out of public and private laboratories. In particular the clarification of whether living organisms could be patented was crucial and had been an ongoing saga between 1971 and 1980 in relation to the Diamond vs. Chakrabarty case. ${ }^{71}$ Second, there was a need to enable the capture of public science funded by the US federal government and thereby exclude others from its benefits. Finally there was an increased emphasis on the international dimensions of all these other policies in order to enable the competitiveness of US firms in global markets. 
Consequently a number of trade-related policies such as the TRIPS agreement at the WTO were vigorously pursued.

In order to capture the results of this new technological saviour of the US economy, policy-makers had to wait until 1980 when the Supreme Court ruling on the Diamond vs. Chakraberty case enabled the patenting of genetically-engineered living organisms. ${ }^{72}$ In particular, it upheld a broad patent covering biotechnology specifically. ${ }^{73}$ Subsequent to this decision the Patent and Trademark Office (USPTO) gradually eased its stand on patenting animals so that by 1988 Harvard was able to patent the Oncomouse. ${ }^{74}$ A more deliberate policy decision was the establishment of the Court of Appeals for the Federal Circuit (CAFC) in 1982, which was the dedicated final appeal court in patent cases. ${ }^{75}$ As a consequence of the establishment of the CAFC, patent cases were increasingly found in favour of the patent holder. ${ }^{76} \mathrm{~A}$ number of important decisions by CAFC in the 1990s enabled patent claims to cover both product and process and, more importantly, enabled research processes to be patented because utility claims were extended to cover future use in research. ${ }^{77}$ Subsequent to these rulings the USPTO amended its guidelines in 2001 so that utility could be 'theoretical' thereby blurring the line between research and commercialisation. $^{78}$

Over a similar time period US policy-makers sought to encourage the commercialisation of new science and technologies developed by public organisations like universities. In particular, two major acts in 1980 were aimed at ensuring the capture of public science by commercial firms. First, the Bayh-Dole Act helped to stimulate technology transfer policies in the US and in other countries. ${ }^{79}$ It aimed to remove limits on the patenting and licensing of federally-funded research undertaken by universities and small businesses; it was subsequently extended to large businesses in 1983. ${ }^{80}$ Second, the Stevenson-Wydler Act encouraged the transfer of technology from the National Institutes of Health (NIH) by setting up an office for such activity and providing information on research as well. ${ }^{81}$ There were a number of other important policy decisions that cemented these changes, reinforcing their impact on the commercialisation of publicly funded research, especially in relation to biomedicine; an illustrative selection of these is outlined in table I.

Table I. Examples of competitiveness policy initiatives in the USA ${ }^{82}$

\begin{tabular}{|l|l|l|}
\hline Date & Policy & Effect \\
\hline 1982 & $\begin{array}{l}\text { Small Business Innovation } \\
\text { Development Act }\end{array}$ & $\begin{array}{l}\text { Required federal funders to allocate 1.25\% of R\&D } \\
\text { budgets to small and medium enterprises. }\end{array}$ \\
\hline 1984 & $\begin{array}{l}\text { National Cooperative } \\
\text { Research Act }\end{array}$ & $\begin{array}{l}\text { Relaxed antitrust rules for joint ventures on research. } \\
\text { Subsequently extended in 1989 to production, } \\
\text { manufacturing and marketing of co-operative R\&D. }\end{array}$ \\
\hline 1986 & $\begin{array}{l}\text { Federal Technology Transfer } \\
\text { Act }\end{array}$ & $\begin{array}{l}\text { Created Cooperative Research and Development } \\
\text { Agreements (CRADA) that enabled firms to access } \\
\text { publicly funded research }\end{array}$ \\
\hline 1995 & $\begin{array}{l}\text { Biotechnology Process } \\
\text { Patent Act }\end{array}$ & $\begin{array}{l}\text { Restricted foreigners from using the processes } \\
\text { involved in products patented in the US. }\end{array}$ \\
\hline
\end{tabular}


The final component of the competitiveness regime was in some ways the most important because it dealt with the ability of US firms to compete in international markets. Again, a number of policy decisions were made that provided a trading advantage for US firms. In particular the Trade Act established a series of processes called 301 and 301 Special that enabled the US to withdraw favourable trade status from those countries that it deemed not to have fulfilled certain demands on intellectual property rights (IPR). ${ }^{83}$ Such policies were institutionalised in the Omnibus Trade and Competitiveness Act (1988) when they became public law. These processes meant that countries refusing to adhere to US demands could be threatened with trade restrictions. ${ }^{84}$ Such international activities designed to promote US interests were pursued through multilateral trade negotiations as well. The most important being the World Trade Organisation (WTO) which introduced the Trade Related Aspects of Intellectual Property (TRIPS) measures. Article 27 of TRIPS meant that all signatories had to enforce biotech patents, whilst Article 33 harmonised patents to a 20-year minimum where non-compliance would entail the loss of trade privileges. ${ }^{85}$

The policy decisions and their repercussions above illustrate the basis for the theoretical claim that scarcity produces markets and that such scarcity has to be manufactured where it does not already exist. If we accept Polanyi's argument on this point then we can show that the practice of the bioeconomy produces scarcity through the demarcation of aspects of the world (eg, biology, genetics) as economic domains that can be incorporated into existing markets or as new markets perhaps with unique characteristics. However, this manufacture of scarcity has to be legitimated in terms of both social value (ie, societal relations) and market value (ie, economic calculation) in a continual process that naturalises both the current and previous value status. ${ }^{86}$ In this sense the policy discourse around the competitiveness of the bioeconomy exists to naturalise the past investment of energy and resources into new genetics and the continuing investment that is being made. In this case the naturalisation of the past investment naturalises the present investment, which, in turn, naturalises the positing of future potential. ${ }^{87}$ In which case, what are the implications of these discourses and practices for the bioeconomy and, in particular, are they detrimental to technoscientific development?

\section{Implications of the neoliberal bioeconomy}

The underlying tenet of neoliberalism is the extension of the market ethic into all areas of social, political and economic life, both as a disciplining mechanism for achieving efficiency in economic activity and as a moral code promoting liberty through private property. Consequently the discourse and practice of competitiveness, tied as it is to neoliberal precepts, promotes the collapse of a distinction between market value and ethical value so that commercial value becomes the overriding principle for political economy (ie, how we organise economic exchange). We can therefore identify a number of detrimental effects that neoliberalism can have in the bioeconomy, of which I will outline one here: the impact on technoscientific development. 
The effect of neoliberalism on technoscience is evident in the current 'productivity crisis' in the biomedical (pharmaceutical and biotechnology) industry. Over the last few years a number of commentators, academics and policy-makers have raised concerns about this productivity crisis. In particular Nightingale and Martin have questioned the 'revolutionary' claims around biotechnology, ${ }^{88}$ although such concerns are also evident in policy and trade circles. The FDA, for example, produced a report in 2004 outlining several problematic features of the pharmaceutical innovation system, ${ }^{89}$ whilst similar concerns have been raised in the trade publications like Genetic Engineering News (GEN) and Modern Drug Discovery (MDD). ${ }^{90}$ The productivity crisis itself relates to the decline in new drug approvals concomitant with rising R\&D expenditure by biomedical firms. Martin et al argue that it is a global crisis that has resulted from industry lock-in to an "innovative paradigm focused on incremental innovation and the pursuit of blockbuster markets" rather than because of over-regulation. ${ }^{91}$ Furthermore, the growing number of new biopharmaceutical approvals that have replaced traditional chemical drugs does not necessarily provide the solution to this problem because of the difficulties in integrating new genetic and genomic technologies into the existing paradigm. ${ }^{92}$

Although the blockbuster model is problematic in relation to the integration of modern biotechnology (eg, pharmacogenetics) and the focus on both a limited number of drug targets and incremental innovation, it has proved particularly profitable for the biomedical industry, including biotech companies such as Amgen and Genentech, which have more recently expanded their research efforts in chemistry and the pursuit of small-molecule drugs. ${ }^{93}$ A market report by McKinnon et al questions the very basis of the productivity crisis itself by arguing that although the number of new drug approvals may not be rising significantly, profits have been impressive. For example, the number of blockbuster drugs has risen from 25 in 1998 to 64 in 2003 and the potential revenue from each new drug has risen by $57 \%$ in the same period. ${ }^{94}$ Thus it has been argued that the consequence of growing $\mathrm{R} \& \mathrm{D}$ expenditure is not necessarily a productivity crisis, but rather that commercial reasons have come to dominate drug development to such an extent that they explain around 30\% of drug development 'failures' in 2000 compared with only $5 \%$ in $1991 .{ }^{95}$

It is evident that competitiveness (ie, the pursuit of market returns) has come to dominate biomedical industry strategies and consequently technoscientific development. However, another pressing issue is whether modern biotechnology has challenged existing innovation strategies and thereby improved on existing healthcare provision through the introduction of new products, or whether it is also stuck in a particular paradigm. To explore this issue it is useful to consider several criticisms of both mainstream pharmaceutical and biotech drugs in relation to their technical 'quality.' With pharmaceuticals, Hubbard and Love have shown that of the drugs approved by the FDA between 1989 and 2000 only $23 \%$ were better than existing products. ${ }^{96}$ However, a similar trend has also been identified in relation to the level of therapeutic advance of biopharmaceuticals. For example, Arundel and Mintzes claim that only 33\% of biopharmaceuticals introduced between 1986 and 2004 showed 'some advance' or more, ${ }^{97}$ whilst Joppi et al claim that only $25 \%$ of biotech products approved by EMEA between 1995 and 2003 "represented therapeutic innovation". ${ }^{9}$ Perhaps the most significant element in this disappointing return is that biotechnology products have predominantly been "for rare diseases with small markets" or more 
simply that "they just plain don't work". ${ }^{99}$ Overall the complexity of modern biotechnology - from gene therapy to stem cells - has so far precluded extensive commercialisation by a biomedical industry still wedded to blockbuster drugs. ${ }^{100}$

\section{Conclusion}

The competitiveness agenda that drives the 'competitive state' entails the reregulation of markets and societies to enable them to produce economic value and growth, ${ }^{101}$ especially in relation to the bioeconomy. ${ }^{102}$ Consequently it may appear contradictory to apply a concept like neoliberalism, based as it is on the idea of market forces, to the biotech industry. However, that is because neoliberalism itself is inherently contradictory implying both state 'roll-back' and 'roll-out' of regulation, as Peck and Tickell argue, as well as the wedding of state power to the extension of markets. ${ }^{103}$ This involves the removal of certain regulations and the imposition of others. In the former case there is the increasing relaxation in pharmaceutical testing regimes highlighted by Abraham and Reed, ${ }^{104}$ whilst the latter is exemplified in increasingly stringent intellectual property (IP) regimes. ${ }^{105}$ Furthermore, biotech IP has been itself framed within an explicitly neoliberal framework that endorses both 'genetic-reductionism' and 'economic-reductionism' as McAfee highlights. ${ }^{106}$

In a sense then there is a self-fulfilling prophecy at work with regards to market value (ie, returns on investment) rather than other forms of value such as 'innovativeness' or 'efficacy'. The ideological discourse of neoliberalism legitimates and naturalises policy processes that have been introduced and encouraged to produce market value from biotechnology, which does not then have to ensure practices of social or ethical value contained in these discourse. Thus the current concern with the efficacy of biotech products, ${ }^{107}$ the 'productivity crisis' in pharmaceuticals, ${ }^{108}$ or the impact of new genetics on competitiveness and healthcare ${ }^{109}$ can be seen as the consequence of the pursuit of a neoliberal discourses and practices, rather than the result of any inherent qualities of new genetics and modern biotechnology.

\section{Acknowledgements}

I wish to thank the referees for their useful comments and the Economic and Social Research Council (ESRC) for funding a seminar series titled Neoliberalism, AntiNeoliberalism and De-ideologisation. ${ }^{110}$ The views expressed here to not represent those of the ESRC. Usual disclaimers apply.

\footnotetext{
${ }^{1}$ A. Lippman. Led (Astray) by Genetic Maps: The Cartography of the Human Genome and Health Care. Social Science Medicine 1992; 35(12).

${ }^{2}$ D. Nelkin and S. Lindee. 1995. The DNA Mystique. New York. W.H. Freeman.

${ }^{3}$ B. Katz Rothman. 1998. Genetic Maps and Human Imaginations. New York: Norton: 13.

${ }^{4}$ R. Lewontin. 1993. The Doctrine of DNA: Biology as Ideology. London: Penguin.

${ }^{5}$ K. McAfee. Geographies of Risk and Difference in Crop Genetic Engineering. The Geographical Review 2004; 94(1).

${ }^{6}$ For example, S. Cunningham-Burley and M. Boulton. 2000. The Social Context of the New Genetics. In The Handbook of Social Studies in Health and Medicine. G. Albrecht, R. Fitzpatrick and S. Scrimshaw, eds. London. SAGE; and P. Atkinson, E. Parsons and K. Featherstone. Professional constructions of family and kinship in medical genetics. New Genetics and Society 2001; 20(1).
} 
${ }^{7}$ A. Hedgecoe. Geneticization, medicalisation and polemics. Medicine, Healthcare and Philosophy 1998; 1; A. Hedgecoe. Reconstructing Geneticization: a Research Manifesto. Health Law Journal 1999; 7; A. Hedgecoe. Ethical boundary work: Geneticization, philosophy and the social sciences. Medicine, Health Care and Philosophy 2001; 4.

${ }^{8}$ See Hedgecoe, op.cit. note 7. For a contrast see H. ten Have. Genetics and culture: The geneticization thesis. Medicine, Health Care and Philosophy 2001; 4.

${ }^{9}$ C. Condit, N. Ofulue and K. Sheedy. Determinism and Mass-Media Portrayals of Genetics. American Journal of Human Genetics 1998; 62.

${ }^{10}$ T. Bubela \& T. Caulfield. Do the print media "hype" genetic research? A comparison of newspaper stories and peer-reviewed research papers. Canadian Medical Association Journal 2004; 170(9).

${ }^{11}$ D. Barben. The Political Economy of Genetic Engineering: The Neoliberal Formation of the Biotechnology Industry. Organization and Environment 1998; 11(4).

${ }^{12}$ I. Helen. Health in Prospect: High-tech Medicine, Life Enhancement and the Economy of Hope. Science Studies 2004; 17.

${ }^{13}$ A. Kerr. 2004. Genetics and Society. London. Routledge.

${ }^{14}$ For example, see N. Brown. Hope Against Hype - Accountability in Biopasts, Presents and Futures. Science Studies 2003; 16. Also see K. Sunder Rajan. 2006. Biocapital. Durham: Duke University Press.

${ }^{15}$ In particular see T. Caulfield. Underwhelmed: Hyperbole, Regulatory Policy, and the Genetics Revolution. McGill Law Journal 2000; 45. Also relevant is U. Fleising. In search of genohype: a content analysis of biotechnology company documents. New Genetics and Society 2001; 20(3).

${ }^{16} \mathrm{~T}$. Mitchell. The work of economics: how a discipline makes its world. European Journal of Sociology 2005; 46(2).

${ }^{17}$ N. Brown and M. Michael. A Sociology of Expectations: Retrospecting Prospects and Prospecting Retrospects. Technology Analysis \& Strategic Management 2003; 15(1).

${ }^{18}$ In particular see D. MacKenzie. The big, bad wolf and the rational market: portfolio insurance, the 1987 crash and the performativity of economics. Economy and Society 2004; 33(3). Also relevant and particularly interesting in general terms is F. Ferraro, J. Pfeffer \& R. Sutton. Economics Language and Assumptions: How Theories Can Become Self-fulfilling. Academy of Management Review 2005; 30(1).

${ }^{19}$ See J. Carrier. 1997.Introduction. In Meanings of the Market. J. Carrier, ed. Oxford. Berg. Also of interest is S. Ghoshal. Bad Management Theories Are Destroying Good Management Practices. Academy of Management Learning and Education 2005; 4(1).

${ }^{20}$ In particular see K. Polanyi. 1957. The economy as instituted process. In Trade and Market in the Early Empires. K. Polanyi, C. Arensberg and H. Pearson, eds. Illinois. Free Press and Falcon's Wing Press. However, also see K. Polanyi. 2001 [1944]. The Great Transformation. Boston. Beacon Press. ${ }^{21}$ Polanyi 1957, op.cit. note 20, p.247.

${ }^{22}$ R. Hull. 2006. The great lie: Markets, freedom and knowledge. In Neoliberal Hegemony. D. Plehwe, B. Walpen and G. Neunhoffer, eds. London: Routledge.

${ }^{23}$ D. Plehwe and B. Walpen. 2006. Between network and complex organization: The making of neoliberal knowledge and hegemony. In Neoliberal Hegemony. D. Plehwe, B. Walpen and G.

Neunhoffer, eds. London: Routledge.

${ }^{24}$ M. Blyth. 2002. Great Transformations. Cambridge. Cambridge University Press.

${ }^{25}$ D. Harvey. 2005. A Brief History of Neoliberalism. Oxford. Oxford University Press.

${ }^{26}$ Blyth 2002, op.cit. note 24. Also C. Hay. The normalizing role of rationalist assumptions in the institutional embedding of neoliberalism. Economy and Society 2004; 33(4).

${ }^{27}$ Harvey 2005, op.cit. note 25. Also Plehwe and Walpen 2006, op.cit. note 22; and W. Carroll and C. Carson. 2006. Neoliberalism, capitalist class formation and the global network of corporations and policy groups. In Neoliberal Hegemony. D. Plehwe, B. Walpen and G. Neunhoffer, eds. London: Routledge.

${ }^{28}$ J. Peck and A. Tickell. Neoliberalizing Space. Antipode 2002; 34(3): 381.

${ }^{29}$ G. Bristow. Everyone's a 'winner': problematising the discourse of regional competitiveness. Journal of Economic Geography 2005; 5.

${ }^{30}$ P. Armstrong. Science, enterprise and profit: ideology in the knowledge-driven economy. Economy and Society 2001; 30(4).

${ }^{31}$ B. Jessop. 2000. The state and the contradictions of the knowledge-driven economy. In Knowledge, Space, Economy. J. Bryson, P. Daniels, N. Henry and J. Pollard, eds. London. Routledge.

${ }^{32}$ Harvey, op.cit. note 25. 
${ }^{33}$ A. Tickell and J. Peck. 2003. Making Global Rules: Globalization or Neoliberalization? In Remaking the Global Economy. J. Peck and H. Yeung, eds. London. SAGE: 166.

${ }^{34}$ Peck and Tickell, op.cit. note 28.

${ }^{35}$ J. Peck. Neoliberalizing states: thin policies/hard outcomes. Progress in Human Geography 2001; 25(3). See also J. Peck. Geography and public policy: constructions of neoliberalism. Progress in Human Geography 2004; 28(3).

${ }^{36}$ N. Brenner and N. Theodore. Cities and the Geographies of "Actually Existing Neoliberalism". Antipode 2002; 34(3): 352 .

${ }^{37}$ Blyth, op.cit. note 24 .

38 For a review see R. Hull. Knowledge and the economy: some critical comments. Economy and Society 2000; 29(2). For a more thorough analysis see G. Hodgson. 1999. Economics and Utopia. London. Routledge.

${ }^{39}$ B. Godin. The Knowledge-Based Economy: Conceptual Framework or Buzzword? Journal of Technology Transfer 2006; 31 .

${ }^{40}$ H. Etzkowitz \& L. Ledesdorff. The dynamics of innovation: from National Systems and "Mode 2" to a Triple Helix of university-industry-government relations. Research Policy 2000; 29.

${ }^{41}$ Harvey, op.cit. note 25, p.19.

${ }^{42}$ See R. Loeppky. International Restructuring, Health and the Advanced Industrial State. New Political Economy 2004; 9(4).

${ }^{43}$ R. Bud. 1998. Molecular Biology and the Long-Term History of Biotechnology. In Private Science.

A. Thackray, ed. Philadelphia. University of Pennsylvania Press.

${ }^{44}$ R. Loeppky. History, technology, and the capitalist state: the comparative political economy of biotechnology and genomics. Review of International Political Economy 2005; 12(2).

${ }^{45}$ Rajan, op.cit. note 14 .

${ }^{46}$ E. Englander. The Political Economy of Biotechnology: Innovation and Politics in an Emerging Industry. Business and Economic History 1991; 20

${ }^{47}$ For a discussion of similar situation in reference to the US railroads in the $19^{\text {th }}$ century, see G. Berk. 2004. Whose Hubris? Brandeis, Scientific Management, and the Railroads. In Constructing Corporate America. K. Lipartito and D. Sicilia, eds. Oxford: Oxford University Press.

${ }^{48}$ EC policy is exemplified in EC. 2005. New Persepctives on the knowledge-based bio-economy: Conference Report. Brussels. European Commission, whilst OECD policy is exemplified in OECD. 2005. The Bioeconomy to 2030: Designing a Policy Agenda. Paris: Organisation for Economic Cooperation and Development.

${ }^{49}$ EC, op.cit. note 48, p.1.

${ }^{50}$ OECD 2005, op.cit. note 48, p.1.

${ }^{51}$ See also EC. 2002. Life sciences and biotechnology - A Strategy for Europe. Brussels. European Commission.

${ }^{52}$ House of Commons (Trade \& Industry Committeee). 2003. UK Biotechnology Industry:

Government Response to the Committee's Twelfth Report of Session 2002-3. London. The Stationery Office.

${ }^{53}$ BIGT. 2003. Improving National Health, Improving National Wealth. London. Bioscience Innovation and Growth Team.

${ }^{54}$ A number of such mapping exercises have been undertaken. For the UK government there is DTI. 2005. Comparative Statistics for the UK, European and US Biotechnology Sectors. London: Department of Trade and Industry. For EuropaBio there is Critical I. 2005. Biotechnology in Europe: 2005 Comparative Study. Lyon. EuropaBio. It is worth noting that both these studies were carried out by the same consultancy.

${ }^{55}$ The first was DTI. 1999. Biotech Clusters. London: Department of Trade and Industry, and the second DTI. 1999. Genome Valley. London: Department of Trade and Industry.

${ }^{56}$ It is noticeable in this policy discourse that the potential of new genetics has been conceived in terms of a particular understanding of genetic technologies and their capabilities. For example, in the UK Prime Minister's foreword to a Department of Health White Paper he states: "As an increasing number of diseases are linked to particular genes or gene sequences, we will be able to target and tailor treatment better to offset their impact and even to avoid the onset of ill-health many years in advance". DH. 2003. Paper Our Inheritance, Our Future. London: The Stationery Office: 1.

${ }^{57}$ Scottish Enterprise. 2004. Scottish Life Sciences Strategy. Glasgow. Scottish Enterprise.

${ }^{58}$ A. Rosiello. 2004. Evalutaing Scottish Enterprise's Cluster Policy in Life Sciences: A Descriptive Analysis. University of Edinburgh. Innogen Working Paper No.16. 
${ }^{59}$ J. Fields. US millionaire Snyder berates Scotland's 'difficult' enterprise culture. The Sunday Herald 23 October 2005.

${ }^{60}$ OBN. 2002. Growth \& Sustainability: the cluster report 2002. Oxford. Oxfordshire Bioscience Network.

${ }^{61}$ Oxford Trust. 2002. Oxford Networks: Medical \& Biosciences Report. Oxford. The Oxford Trust.

${ }^{62}$ H. Gottweis. 1998. Governing Molecules. London. MIT Press.

${ }^{63} \mathrm{r}$ (with ABRC and the Royal Society). 1980. Biotechnology: Report of a Joint Woking Party. London. HMSO: 7-8.

${ }^{64}$ House of Lords (Select Committee on Science and Technology). 1993. Regulation of the United Kingdom Biotechnology Industry and Global Competitiveness. London. HMSO: 9

${ }^{65} \mathrm{~S}$. Wright. The social warp of science: Writing the history of genetic engineering policy. Science, Technology \& Human Values 1993; 18(1). See also S. Wright. 1998. Molecular politics in a global economy. In Private Science. A. Thackray, ed. Philadelphia. University of Pennsylvania Press.

${ }^{66}$ In particular see US House of Representatives (Committee on Science and Technology). 1981.

Commercialization of Academic Biomedical Research. Washington. US Government Printing Office. Also see OTA. 1984. Commercial Biotechnology: AN International Analysis. Washington. US Congress, Office of Technology Assessment.

${ }^{67}$ Wright 1998, op.cit. note 65, p. 91. However, also see M. Kenney. 1998. Biotechnology and the creation of a new economic space. In Private Science. A. Thackray, ed. Philadelphia. University of Pennsylvania Press.

${ }^{68}$ On policy discourse see DTI. 2003. Innovation Report - Competing in the global economy: The innovation challenge. London: Department of Trade and Industry. On the academic debate see L. Tyson. 1992. Who's Bashing Whom? Trade Conflict in High-Technology Industries. Washington, DC: Institute for International Economics. For a critique of the competitiveness concept and its policy misuses see P. Krugman. 1996. Pop Internationalism. London. MIT Press.

${ }^{69}$ See G. Bridge, P. McManus and T. Marsden. Guest Editorial: The Next new thing? Biotechnology and its discontents. Geoforum 2003; 34. For a more thorough analysis of some of these issues see K. Birch. 2007. The Social Construction of the Biotech Industry. In New Genetics, New Social Formations. P. Glasner and P. Atkinson, eds. London. Routledge.

${ }^{70}$ M. Kitson, R. Martin and P. Tyler. Regional competitiveness: An elusive yet key concept? Regional Studies 2004; 38(9).

${ }^{71}$ B. Coriat, F. Orsi and O. Weinstein. Does biotech reflect a new science-based innovation regime? Industry and Innovation 2003; 10(3).

${ }^{72}$ R. Iwasaka. From Chakrabaty to Chimeras: the growing need for evolutionary biology in patent law. Yale Law Journal 2000; 109(6).

${ }^{73}$ D. Mowery, R. Nelson, B. Sampat and A. Ziedonis. The growth of patenting and licensing by US universities: An assessment of the effects of the Bayh-Dole act of 1980. Research Policy 2001; 30.

${ }^{74}$ G. Dutfield. 2003. Intellectual Property Rights and the Life Science Industries. Aldershot. Ashgate.

${ }^{75}$ Mowery et al, op.cit. note 73.

${ }^{76}$ M. Katz and J. Ordover. R\&D cooperation and competition. Brookings Papers on Economic Activity: Microeconomics 1990.

${ }^{77}$ W. Kaplan and S. Krimsky. Patentability of biotechnology inventions under the PTO utility guidelines: Still uncertain after all these years? The Journal of Biolaw and Business 2001; Special Supplement. See also S. Maebius. 1996. The new era of process patentability Washington. Foley \& Lardner.

${ }^{78}$ G. Laurie. 2003. Intellectual property protection of biotechnological inventions and related materials. University of Edinburgh. Innogen Working Paper.

${ }^{79}$ J. Senker, C. Enzing, P-B. Joly and T. Reiss. European exploitation of biotechnology - do government policies help? Nature Biotechnology 2000; 18.

${ }^{80}$ S. Slaughter and G. Rhoades. The emergence of a competitiveness research and development policy coalition and the commercialization of academic science and technology. Science, Technology \& Human Values 1996; 21(3). See also J. Poyago-Theotoky, J. Beath and D. Siegel. Universities and fundamental research: Reflections on the growth of university-industry partnerships. Oxford Review of Economic Policy 2002; 18(1); and B. Sampat. Patenting and US academic research in the $20^{\text {th }}$ century: The world before and after Bayh-Dole. Research Policy 2006; 35. As important perhaps was that the Antitrust Division also promoted licensing with a hand's off approach to policing such joint activity, see P. Drahos and J. Braithewaite. 2002. Information Feudalism: Who Owns the Knowledge Economy. London. Earthscan Publications. 
${ }^{81}$ Slaughter and Rhoades, op. cit. note 80.

${ }^{82}$ The list of legal and policy changes is derived from a number of sources such as Slaughter and Rhoades, op.cit. note 80; Katz and Ordover, op.cit. note 76; G. Kuhlman. Alliances for the future: Cultivating a cooperative environment for biotech success. Berkeley Technology Law Journal 1996; 11(2); and E. Buctuanon. Globalization of biotechnology: the agglomeration of dispersed knowledge and information and its implications for the political economy of technology in developing countries. New Genetics and Society 2001; 20(1). See also Birch, op.cit. note 69.

${ }^{83}$ Drahos and Braithewaite, op.cit. note 80.

${ }^{84}$ Slaughter and Rhoades, op.cit. note 80.

${ }^{85}$ C. May. 2000. A Global Political Economy of Intellectual Property Rigths. London. Routledge.

${ }^{86}$ See D. Graeber. 2001. Toward an Anthropological Theory of Value: The False Coin of our own Dreams. New York. Palgrave.

${ }^{87}$ Brown and Michael, op.cit. note 17.

${ }^{88}$ P. Nightingale and P. Martin. The myth of the biotech revolution. Trends in Biotechnology 2004; 22(11).

${ }^{89}$ FDA. 2004. Innovation or Stagnation? US Department of Health and Human Services. Food and Drug Administration.

${ }^{90}$ For example, V. Mehta. Biotech's Changing Competitive Landscape. Genetic Engineering News 2006; 27(1); A. Thayer. Blockbuster model breaking down. Modern Drug Discovery 2004; June.

${ }^{91}$ For example, P. Martin, J. Abraham, C. Davis and A. Kraft. 2006. Understanding the 'Productivity Crisis' in the Pharmaceutical Industry: Over-regulation or lack of innovation? In New Technologies in Health Care. A. Webster, ed. Hampshire. Palgrave Macmillan: 179-180.

${ }^{92}$ A. Webster, Martin, P., Lewis, G. and Smart, A. Integrating pharmacogenetics into society: in search of a model. Nature Reviews: Genetics 2004; 5. See also M. Hopkins et al. Putting pharmacogenetics into practice. Nature Biotechnology 2006; 24(4).

${ }^{93}$ C. Bowe. 'Big biotech' fears becoming a victim of its own success. The Financial Times 20 July 2006.

${ }^{94}$ R. McKinnon, K. Worzel, G. Rotz and H. Williams. 2004. Crisis? What Crisis? A Fresh Diagnosis of Big Pharma's R\&D Productivity Crunch. London. Marakon Associates.

${ }^{95}$ I. Cockburn. 2006. Is the Pharmaceutical Industry in a Productivity Crisis? Paper prepared for the NBER Innovation Policy and the Economy Conference, 19 April.

${ }^{96}$ T. Hubbard and J. Love. A New Trade Framework for Global Healthcare R\&D. PLoS Biology 2004; 2(2).

${ }^{97}$ A. Arundel and B. Mintzes. 2004. The Benefits of Biopharmaceuticals. University of Edinburgh: Innogen Working Paper No.14.

${ }^{98}$ For example, R. Joppi, V. Bertele and S. Garattini. Disappoiting biotech. BMJ 2005; 331: 895.

${ }^{99}$ D. Rasnick. The biotechnology bubble machine. Nature Biotechnology 2003; 21: 356.

${ }^{100}$ R. Glassman and A. Sun. Biotechnology: identifying advances from the hype. Nature Reviews Drug Discovery 2004; 3

${ }^{101}$ H. Lofgren \& M. Benner. The Bio-Economy and the Competition State: Transcending the Dichotomy between Coordinated and Liberal Market Economies. New Political Science 2007; in press.

${ }^{102}$ A. Hansen. Biotechnology Regulation: Limiting or Contributing to Biotech Development? New Genetics and Society 2001; 20(3).

${ }^{103}$ Peck and Tickell, op.cit. note 28; Tickell and Peck 2003, op.cit. note 33.

${ }^{104}$ See J. Abraham and T. Reed. Progress, Innovation and Regulatory Science in Drug Development: The Politics of International Standard-Setting. Social Studies of Science 2002; 32 (3). Also see J. Abraham \& T. Reed. 2003. Globalization of Medicines Control. In Regulation of the Pharmaceutical Industry. J. Abraham and H. Lawton Smith, eds. Hampshire. Palgrave Macmillan.

${ }^{105}$ May, op.cit. note 85.

${ }^{106}$ K. McAfee. Neoliberalism on the molecular scale. Economics and genetic reductionism in biotechnology battles. Geoforum 2003; 34 .

${ }^{107}$ Joppi et al, op.cit. note 98.

${ }^{108}$ Martin et al, op.cit. note 91 .

${ }^{109}$ Glassman and Sun, op.cit. note 100

$110 \mathrm{http} / /$ www.cppr.ac.uk/centres/cppr/esrcneoliberalismseminar/ 